\title{
Interleukin-7 receptor Thr244lle gene polymorphism and the risk of systemic lupus erythematosus
}

\author{
Piotr Piotrowski ${ }^{1}$, Marzena Olesińska², Paweł P. Jagodziński \\ ${ }^{1}$ Department of Biochemistry and Molecular Biology, Poznan University of Medical Sciences, Poland \\ 2 Institute of Rheumatology, Warsaw, Poland
}

ABSTRACT

Aim. Recently, the IL-7 receptor (IL-7R) C>T (rs6897932) single nucleotide polymorphism (SNP), which causes a Thr244lle substitution in the IL-7R $\alpha$-chain, has been suggested as a risk factor for SLE.

Material and Methods. Using high-resolution melting curve analysis we studied the distribution of the IL-7R C>T polymorphism in SLE patients $(n=281)$ and control subjects $(n=541)$ in the Polish population.

Results. We did not find significant differences in the distribution of the IL-7R C $>$ T genotype and alleles between SLE patients and controls. However, in the dominant model ( $T / T$ and $C / T$ vs $C / C$ genotypes), we observed a protective effect of the IL-7R C >T polymorphism against the presence of neurological manifestations of SLE $\left[\mathrm{OR}=0.3631(95 \% \mathrm{Cl}=0.1895-0.6954), \mathrm{p}=0.0017, \mathrm{p}_{\text {corr }}=0.0323\right]$ and the presence of anti-Scl-70 antibodies (Ab) $\left[\mathrm{OR}=0.3141(95 \% \mathrm{Cl}=0.1503-0.6561), \mathrm{p}=0.0014, \mathrm{p}_{\text {corr }}=0.0266\right]$.

Conclusion. Our studies suggest that the IL-7R C>T (rs6897932) polymorphism might be involved in the neurological manifestations and the presence of anti-Scl-70 Abs in patients with SLE.

Keywords: Interleukin-7 receptor, SNP, SLE.

\section{Introduction}

Systemic lupus erythematosus (SLE) is a chronic autoimmune disorder in which the immune system of the host attacks its own tissues [1]. The SLE immune cells are characterized by abnormal signaling in $\mathrm{CD}^{+} \mathrm{T}$ cells as well as abundant autoantibody biosynthesis by $B$ cells [1-3]. This disease can affect the kidneys, joints, skin, lungs, brain, and other organ systems, resulting in defective functioning of organs, as observed in clinical findings of SLE [1]. Familial and genome-wide association studies have suggested many genes that potentially play a role in SLE development, phenotypes and antibody profiles. Exposure to various exogenous factors such as ultraviolet light, drugs, chemicals, pollutants, and bacterial and viral infections all contribute to SLE development. The underlying cause of SLE remains unknown; however, it is accepted that the genetic components of the host and environmental factors make the host vulnerable to this autoimmune disorder $[4,5]$.

Recently, an increased body of evidence has demonstrated an association of abnormal interleukin-7 (IL-7) signaling with aberrant functions of immune cells and autoimmunity [9]. IL-7 signaling plays an elementary role in B lymphopoiesis, thymocyte maturation, peripheral $T$ cell homeostasis and immune tolerance [10-12]. IL-7 receptor (IL-7R) is a heterodimer comprising IL-7Ra and the common $y$-chain, which is also shared by IL-2R, IL-4R, IL-9R, IL-15R, and IL-21R [13, 14]. The IL-7R C>T (rs6897932) polymorphism causes a Thr244lle substitution in the IL-7R $\alpha$-chain, thereby changing the ratio of membrane-bound to soluble IL-7R, which is implicated in the pathogenesis of autoimmune diseases $[15$, 
16]. It has been demonstrated that the Thr244lle substitution can be associated with some autoimmune diseases [15, 17-19]. Recently, the IL-7R C>T SNP has also been recognized as a risk factor for SLE development [18]. Therefore, we evaluated whether the IL-R7 C>T SNP is a genetic risk factor for SLE in the Polish population. Because SLE is a heterogeneous disorder, we also examined the association of this polymorphism with different disease phenotypes and antibody profiles.

\section{Material and Methods}

\section{Patients and controls}

Medical records data for two hundred and eighty-one women fulfilling the American College of Rheumatology Classification criteria for SLE were collected for the study in a random manner at the Institute of Rheumatology in Warsaw, Poland [20, 21]. The control group comprised five hundred and forty-one unrelated healthy female volunteers that were selected during medical examination at the Institute of Mother and Child in Warsaw, Poland. The women with SLE and the controls were of Polish Caucasian origin and of similar age. The mean age was $37 \pm 8$ years for the SLE patients at diagnosis and $36 \pm 7$ years for the controls. All participating subjects provided written consent. The study procedures were approved by the Local Ethical Committee of Poznan University of Medical Sciences in Poznan, Poland.

\section{Genotyping}

DNA was isolated from peripheral leukocytes using a salting-out procedure. The IL-7R C > T (rs6897932) DNA fragment (135bp) was amplified using the primers 5' TGAGACCCTACCCCCACT $3^{\prime}$ and 5' GCCAAGATGACCAACAGAG 3'. This polymorphism was then genotyped by high-resolution melting curve analysis (HRM) on a Light Cycler 480 system (Roche Diagnostics, Mannheim, Germany). The IL-7R C>T polymorphisms were verified by commercial sequencing analysis.

\section{Statistical analysis}

The prevalence of genotypes in patients and controls was examined for deviation from Hardy-Weinberg equilibrium using exact and log likelihood ratio chi-squared $\left(X^{2}\right)$ tests [http://ihg.gsf.de/cgi-bin/hw/hwa1.pl]. The polymorphism was tested for association with the SLE incidence using the $x^{2}$ test for trend $\left(p_{\text {trend }}\right)$. The $x^{2}$ test was employed to examine differences in genotypic and allelic distribution between patients and controls, and a $p$ value $<0.05$ was considered statistically significant. Odds ratios (ORs) and 95\% confidence intervals (95\% $\mathrm{Cls})$ were calculated. The association of the $I L-7$ receptor (IL-7R) C>T SNP polymorphism with clinical manifestations and the presence of autoantibodies was evaluated by $\mathrm{X}^{2}$ test. The Bonferroni correction for multiple comparisons was used, and both $p$ values, before $(p)$ and after correction $\left(\mathrm{p}_{\text {corr }}\right)$, were evaluated.

\section{Results}

\section{Prevalence of IL-7R C>T (rs6897932) genotypes and alleles in SLE patients and controls.}

The genotypic prevalence of the IL-7R C>T polymorphism did not significantly deviate from Hardy-Weinberg equilibrium between patients with SLE and healthy controls. The number of genotypes and the ORs and 95\% Cls for the IL-7R C>T SNP are listed in Table 1. We did not observe association of IL-7R C>T SNP with SLE development. The OR for SLE patients with the IL-7R TT genotype was $0.5906(95 \% \mathrm{Cl}=0.2927-1.192$, $p=0.1378$ ) the OR for the CT genotype was 1.008 $(95 \% \mathrm{Cl}=0.7401-1.373, \mathrm{p}=0.9602)$, the OR for the TT and C/T genotypes was $0.9397(95 \% \mathrm{Cl}=0.6988-$ 1.264, $p=0.6803)$, and the OR for the $C$ allele was

Table 1. Prevalence of the IL-7R C>T (rs6897932) polymorphism in SLE patients and controls

\begin{tabular}{|c|c|c|c|c|c|c|}
\hline$I L-7 R C>T$ & $\begin{array}{c}\text { SLE } \\
\mathrm{n}=281\end{array}$ & $\begin{array}{l}\text { Controls } \\
n=541\end{array}$ & $\mathrm{OR}$ & $95 \% \mathrm{Cl}$ & P-value ${ }^{e}$ & $P_{\text {trend }}$ \\
\hline Genotype frequency & & & & & & \\
\hline $\mathrm{C} / \mathrm{C}$ & $174(0.62)$ & $327(0.61)$ & Reference & & & \\
\hline $\mathrm{C} / \mathrm{T}$ & $96(0.34)$ & $179(0.33)$ & $1.008^{\mathrm{a}}$ & $(0.7401-1.373)$ & $0.9602^{\mathrm{a}}$ & \\
\hline $\mathrm{T} / \mathrm{T}$ & $11(0.04)$ & $35(0.06)$ & $0.5906^{\mathrm{b}}$ & $(0.2927-1.192)^{b}$ & $0.1378^{b}$ & 0.3600 \\
\hline$C / T+T / T$ & $107(0.38)$ & $214(0.39)$ & $0.9397^{c}$ & $(0.6988-1.264)^{c}$ & $0.6803^{c}$ & \\
\hline Minor allele frequency & & & & & & \\
\hline $\mathrm{T}$ & 0.21 & 0.23 & $0.8891^{d}$ & $0.6941-1.139^{d}$ & $0.3517^{d}$ & \\
\hline
\end{tabular}

The Odds Ratio (OR) was calculated for patients ${ }^{a}\left(\mathrm{C} / \mathrm{T}\right.$ vs $\mathrm{C} / \mathrm{C}$ genotype), ${ }^{\mathrm{b}}\left(\mathrm{T} / \mathrm{T}\right.$ vs $\mathrm{C} / \mathrm{C}$ genotype), ${ }_{1}^{\mathrm{c}}(\mathrm{T} / \mathrm{T}$ and $\mathrm{C} / \mathrm{T}$ vs $\mathrm{C} / \mathrm{C}$ genotype). We also determined the $0 \mathrm{R}$ for the patients' minor allele; ${ }^{\mathrm{d}}\left(\mathrm{T}\right.$ allele vs $\mathrm{C}$ allele); ${ }^{\mathrm{e}} \chi^{2}$ test. 
$0.8891(95 \% \mathrm{Cl}=0.6941-1.139, \mathrm{p}=0.3517)$. The $\mathrm{p}$ value of the $X^{2}$ test for the trend observed for the IL-7R $C>T$ polymorphism was also not statistically significant $\left(p_{\text {trend }}=0.3600\right)$.

Association of the IL-7R C >T SNP with the presence of autoantibodies and clinical manifestations in patients with SLE.

In the dominant model ( $\mathrm{T} / \mathrm{T}$ and $\mathrm{C} / \mathrm{T}$ vs $\mathrm{C} / \mathrm{C}$ genotype), we observed a significant protective effect of the IL-7R $C>T$ polymorphism against the presence of neurological manifestations of SLE [OR $=0.3631(95 \% \mathrm{Cl}=0.1895-$ 0.6954 ), $p=0.0017, p_{\text {corr }}=0.0323$ ] (Table 2). We also found a statistically significant protective effect of the IL-7R C>T SNP against the presence of anti-Scl-70 Abs [OR $=0.3141(95 \% \mathrm{Cl}=0.1503-0.6561), \mathrm{p}=0.0014$, $\left.p_{\text {corr }}=0.0266\right]$ (Table 3). However, we did not find any significant differences between the Systemic Lupus Erythematosus Disease Activity Index (SLEDAI) at diagnosis and the IL-7R C>T genotypes.

\section{Discussion}

Abnormal concentrations of IL-7R and IL-7R $\alpha$ on T cells have been demonstrated in blood plasma from patients with SLE [22-24]. The IL-7R levels were significantly higher in SLE patients than in controls and correlated with SLEDAI scores, especially nephritis [22]. In addition to this finding, Kim [23] demonstrated increased levels of IL-7Ra in low effector memory CD8 ${ }^{+} \mathrm{T}$ cells, which may affect tissue damage via CD244-mediated cytotoxicity in patients with SLE. Furthermore, Wang [24], using a mouse model of SLE-like serology, found that the function of IL-7R was required for reintroducing RAG proteins into antigen-activated early memory plasma B cells or pre-plasma B cells and contributed to the maintenance of humoral tolerance. Therefore, the genetic variants of IL-7R $\alpha$ might influence different SLE phenotypes and antibody profiles.

In conclusion, we did not observe a contribution of the IL-7R C>T polymorphism to SLE development in the

Table 2. Distribution of the IL-7RC CT (rs6897932) polymorphism among SLE patients with different clinical manifestations

\begin{tabular}{|c|c|c|c|c|c|c|}
\hline \multirow[b]{2}{*}{ Characteristic } & \multicolumn{4}{|c|}{ Genotype distribution } & \multicolumn{2}{|c|}{$\mathrm{MAF}^{\mathrm{d}}$} \\
\hline & $\begin{array}{c}\mathrm{C} / \mathrm{C} \\
\mathrm{SLE} E^{\mathrm{a}} / \mathrm{SLE}^{\mathrm{b}}\end{array}$ & $\begin{array}{c}\mathrm{C} / \mathrm{T} \\
\mathrm{SLE} \mathrm{E}^{\mathrm{a}} / \mathrm{SLE}^{\mathrm{b}}\end{array}$ & $\begin{array}{c}\mathrm{T} / \mathrm{T} \\
\mathrm{SLE} \\
\mathrm{SLE}^{\mathrm{b}}\end{array}$ & $\begin{array}{c}\text { Odds ratio }(95 \% \mathrm{Cl}) \text {, } \mathrm{p}^{\mathrm{c}} \\
\mathrm{T} / \mathrm{T}+\mathrm{C} / \mathrm{T} \text { vs } \mathrm{C} / \mathrm{C}\end{array}$ & $\mathrm{SLE}^{\mathrm{a}}$ & $S L E^{b}$ \\
\hline Malar rash & $91 / 83$ & $49 / 47$ & $6 / 5$ & & 0.21 & 0.21 \\
\hline Discoid rash & $52 / 122$ & $28 / 68$ & $4 / 7$ & & 0.21 & 0.20 \\
\hline Phototosensitivity & $79 / 95$ & $43 / 53$ & $7 / 4$ & & 0.22 & 0.20 \\
\hline Oral or nasopharyngeal & $67 / 107$ & $39 / 57$ & $5 / 6$ & & 0.22 & 0.20 \\
\hline Arthritis & $39 / 135$ & $22 / 74$ & $3 / 8$ & & 0.22 & 0.21 \\
\hline Serositis & $31 / 143$ & $17 / 79$ & $2 / 9$ & & 0.21 & 0.21 \\
\hline Renal & $84 / 90$ & $46 / 50$ & $7 / 4$ & & 0.22 & 0.20 \\
\hline Neurologic & $51 / 123$ & $12 / 84$ & $2 / 9$ & $0.3631(0.1895-0.6954)^{\prime} p=0.0017$ & 0.12 & 0.24 \\
\hline Hematologic & $56 / 118$ & $30 / 66$ & $5 / 6$ & & 0.22 & 0.21 \\
\hline Immunologic & $84 / 90$ & $43 / 53$ & $10 / 1$ & & 0.23 & 0.19 \\
\hline ANA & $174 / 174$ & $96 / 96$ & $11 / 11$ & & & \\
\hline
\end{tabular}

Comparison of genotype frequencies between patients (SLE $)$ with and patients (SLEb) without a particular manifestation was performed by ${ }^{c} \chi^{2}$ test, minor allele frequency ${ }^{d}$.

Table 3. Effect of the IL-7R C>T (rs6897932) polymorphism on the presence of various autoantibodies in patients with SLE

\begin{tabular}{|c|c|c|c|c|c|c|}
\hline \multirow[b]{2}{*}{ Autoantibodies } & \multicolumn{4}{|c|}{ Genotype distribution } & \multicolumn{2}{|c|}{$\mathrm{MAF}^{\mathrm{d}}$} \\
\hline & $\begin{array}{c}\mathrm{C} / \mathrm{C} \\
\mathrm{SLE}^{\mathrm{a}} / \mathrm{SLE} E^{\mathrm{b}}\end{array}$ & $\begin{array}{c}\mathrm{T} / \mathrm{C} \\
\mathrm{SLE}^{\mathrm{a}} / \mathrm{SLE} \mathrm{E}^{\mathrm{b}}\end{array}$ & $\begin{array}{c}\mathrm{T} / \mathrm{T} \\
\mathrm{SLE}^{\mathrm{a}} / \mathrm{SLE}^{\mathrm{b}}\end{array}$ & $\begin{array}{c}\text { Odds Ratio }(95 \% \mathrm{Cl})^{\mathrm{a}} \text {, } \mathrm{p}^{\mathrm{c}} \\
\mathrm{T} / \mathrm{T} \text { and T/C vs C/C }\end{array}$ & SLE ${ }^{a}$ & SLE \\
\hline anti-dsDNA & $58 / 116$ & $31 / 65$ & $7 / 4$ & & 0.23 & 0.20 \\
\hline anti-Smith & $15 / 159$ & $8 / 88$ & $2 / 9$ & & 0.24 & 0.21 \\
\hline anti-snRNP & $33 / 141$ & $17 / 79$ & $6 / 5$ & & 0.26 & 0.20 \\
\hline anti-Ro & $28 / 146$ & $15 / 81$ & $3 / 8$ & & 0.23 & 0.21 \\
\hline anti-La & $23 / 151$ & $12 / 84$ & $3 / 8$ & & 0.24 & 0.21 \\
\hline anti-Scl-70 & $43 / 131$ & $7 / 89$ & $3 / 8$ & $0.3141(0.1503-0.6561), p=0.0014$ & 0.12 & 0.23 \\
\hline
\end{tabular}

Comparison of genotype frequencies between patients (SLE $)$ with and patients $\left(S L^{b}\right)$ without an autoantibody was performed by $\chi^{c}$ test. minor allele frequency. 
Polish population. Our results were contradictory to the findings of Wang [18], who demonstrated the IL-7R C gene variant as a risk factor for SLE in their studied Chinese population. However, in our study we observed a significant association between the IL-7R C>T polymorphism and the presence of neurologic manifestations in patients with SLE and the presence of anti-Scl70 Abs. In contrast, Wang [18] did not observe an association of this SNP with any clinical features of SLE.

The IL-7R C gene variant has been demonstrated as a risk factor for multiple sclerosis (MS), type I diabetes (T1D), chronic inflammatory arthropathies and atopic dermatitis $[15,17,19,25,26]$. The other SNP, rs10213865, being in complete linkage with IL-7R C $>T$, has been associated with sarcoidosis [27]. The IL-7R C>T polymorphism has also been associated with the risk of hematopoietic cell transplantation relapse in patients with hematological malignancies, and with mortality among untreated HIV-infected Zimbabwean individuals $[28,29]$. Moreover, other genetic variations in IL-7R are implicated in inhalation allergy, Omenn syndrome (MIM 603554), graft-versus host disease, inflammatory bowel disease and primary biliary cirrhosis [30-34].

The role of the IL-7R C>T polymorphism in the development of autoimmunity has been evaluated in some studies [15, 16, 35-37]. Gregory [15] demonstrated that this polymorphism is situated inside of the alternatively spliced exon 6 of $I L-7 R$ and disrupts an exonic splicing silencer, which alters the ratio of soluble and membrane-bound IL-7R isoforms. McKay [35] demonstrated that two IL-7R haplotypes having the IL-7R $C>T$ SNP contributed to the levels of mRNA encoding the sIL-7R isoforms. McKay [35] also showed that this MS susceptibility haplotype was accompanied by the over-presentation of sIL-7R isoforms in the peripheral blood of patients with primary progressive MS. These findings were confirmed by Lundström [16], who observed that individuals with MS with the IL7R CC genotype displayed an increased level of circulating sIL-7Ra. They also demonstrated that sIL-7Ra potentiates IL-7 bioactivity, contributing to the increased risk of autoimmunity in subjects with a genotype linked to heightened sIL7Ra [16]. The sIL-7Ra levels also correlated with the IL-7R C risk allele in patients with T1D [36]. Recently, Kreft [37] demonstrated that sIL-7Ra levels corresponded to the IL-7R C risk allele and abnormal IL-7; therefore, the IL-7Ra concentration may influence the responsiveness of IL-7Ra ${ }^{+} T$ cells.

In conclusion, our study suggests that the IL-7R T gene variant may protect against neurological manifestations of SLE and the presence of anti-Scl-70 Abs.
However, to confirm the role of the IL-7R C>T SNP in SLE, similar studies should be conducted with larger samples of different ethnicities.

\section{Acknowledgements}

The technical assistance of Ms. Agnieszka Hertel is gratefully acknowledged.

\section{Conflict of interest statement}

The authors declare no conflict of interest.

\section{Funding sources}

Supported by grant no. 502-01-01124182-07474 from the Poznan University of Medical Sciences.

\section{References}

1. Lewis JE, Fu SM, Gaskin F. Autoimmunity, end organ damage, and the origin of autoantibodies and autoreactive $\mathrm{T}$ cells in systemic lupus erythematosus. Discov Med 2013;15:85-92.

2. Calero I, Sanz I. Targeting B cells for the treatment of SLE: the beginning of the end or the end of the beginning? Discov Med 2010;10:416-424.

3. Januchowski R, Wudarski M, Chwalińska-Sadowska $H$, Jagodzinski PP. Prevalence of ZAP-70, LAT, SLP-76, and DNA methyltransferase 1 expression in CD4+ T cells of patients with systemic lupus erythematosus. Clin Rheumatol 2008;27:21-27.

4. Muniz Caldas CA, Freire de Carvalho J. The role of environmental factors in the pathogenesis of non-organ-specific autoimmune diseases. Best Pract Res Clin Rheumatol 2012;26:5-11.

5. Jönsen A, Bengtsson AA, Nived O, Truedsson L, Sturfelt G. Gene-environment interactions in the aetiology of systemic lupus erythematosus. Autoimmunity 2007;40:613617.

6. Costa-Reis P, Sullivan KE. Genetics and epigenetics of systemic lupus erythematosus. Curr Rheumatol Rep 2013;15:369.

7. Zhang J, Zhang Y, Yang J, Zhang L, Sun L, Pan HF et al. Three SNPs in chromosome 11q23.3 are independently associated with systemic lupus erythematosus in Asians. 1. Hum Mol Genet 2014;23:524-533.

8. Cui $Y$, Sheng $Y$, Zhang $X$. Genetic susceptibility to SLE: recent progress from GWAS. J Autoimmun 2013;41:25-33.

9. Lundström W, Fewkes NM, Mackall CL. IL-7 in human health and disease. Semin Immunol 2012;24:218-224.

10. Corfe SA, Paige CJ. The many roles of IL-7 in B cell development; mediator of survival, proliferation and differentiation. Seminars in Immunology 2012;24:198-208.

11. Hong C, Luckey MA, Park JH. Intrathymic IL-7: the where, when, and why of IL-7 signaling during T cell development. Seminars in Immunology 2012;24:151-158.

12. Jiang Q, Huang J, Li WQ, Cavinato T, Keller JR, Durum SK. Role of the intracellular domain of IL-7 receptor in T cell development. The Journal of Immunology 2007;178:228234.

13. Rochman Y, Spolski R, Leonard WJ. New insights into the regulation of $\mathrm{T}$ cells by gamma(c) family cytokines. Nat Rev Immunol 2009;9:480-490. 
14. Walsh ST. Structural insights into the common $y$-chain family of cytokines and receptors from the interleukin-7 pathway. Immunol Rev 2012;250:303-316.

15. Gregory SG, Schmidt S, Seth P, Oksenberg JR, Hart J, Prokop A et al. for the Multiple Sclerosis Genetics Group. Interleukin 7 receptor alpha chain (IL7R) shows allelic and functional association with multiple sclerosis. Nat Genet 2007:39:1083-1091.

16. Lundström W, Highfill S, Walsh ST, Beq S, Morse E, Kockum I et al. Soluble IL7Ra potentiates IL-7 bioactivity and promotes autoimmunity. Proc Natl Acad Sci U S A 2013;110:E1761-1770.

17. Santiago JL, Alizadeh BZ, Martínez A, Espino L, de la Calle $\mathrm{H}$, Fernández-Arquero $\mathrm{M}$ et al. Study of the association between the CAPSL-IL7R locus and type 1 diabetes. Diabetologia 2008;51:1653-1658.

18. Wang XS, Wen PF, Zhang M, Hu LF, Ni J, Qiu LJ et al. Interleukin-7 receptor single nucleotide polymorphism rs6897932 (C/T) and the susceptibility to systemic lupus erythematosus. Inflammation 2014;37:615-620.

19. Hoffjan S, Beygo J, Akkad DA, Parwez Q, Petrasch-Parwez E, Epplen JT. Analysis of variation in the IL7RA and IL2RA genes in atopic dermatitis. J Dermatol Sci 2009;55:138-140.

20. Tan EM, Cohen AS, Fries JF, Masi AT, McShane DJ, Rothfield NF et al. The 1982 revised criteria for the classification of systemic lupus erythematosus. Arthritis Rheum 1982;25:1271-1277.

21. Hochberg MC. Updating the American College of Rheumatology revised criteria for the classification of systemic lupus erythematosus. Arthritis Rheum 1997;40:1725.

22. Badot V, Luijten RK, van Roon JA, Depresseux G, Aydin S, Van den Eynde BJ et al. Serum soluble interleukin 7 receptor is strongly associated with lupus nephritis in patients with systemic lupus erythematosus. Ann Rheum Dis 2013;72:453-456.

23. Kim JS, Cho BA, Sim JH, Shah K, Woo CM, Lee EB et al. IL-7Ralow memory CD8+ T cells are significantly elevated in patients with systemic lupus erythematosus. Rheumatology (Oxford) 2012;51:1587-1594.

24. Wang YH, Diamond B. B cell receptor revision diminishes the autoreactive $B$ cell response after antigen activation in mice. J Clin Invest 2008;118:2896-2907.

25. O'Doherty C, Alloza I, Rooney M, Vandenbroeck K. IL7RA polymorphisms and chronic inflammatory arthropathies. Tissue Antigens 2009;74:429-431.

26. Sombekke MH, van der Voort LF, Kragt JJ, Nielsen JM, Guzel H, Visser A et al. Relevance of IL7R genotype and mRNA expression in Dutch patients with multiple sclerosis. Mult Scler 2011;17:922-930.

27. Heron M, Grutters JC, van Moorsel $\mathrm{CH}$, Ruven HJ, Huizinga TW, van der Helm-van Mil AH et al. Variation in IL7R predisposes to sarcoid inflammation. Genes Immun 2009;10:647-653.

28. Shamim Z, Spellman S, Haagenson M, Wang T, Lee SJ, Ryder LP et al. Polymorphism in the interleukin-7 receptor-alpha and outcome after allogeneic hematopoietic cell transplantation with matched unrelated donor. Scand J Immunol 2013;78:214-220.

29. Hartling HJ, Thørner LW, Erikstrup C, Zinyama R, Kallestrup P, Gomo E et al. Polymorphisms in the interleukin-7 receptor $\alpha$ gene and mortality in untreated HIV-infected individuals. AIDS 2013;27:1615-1620.

30. Anderson CA, Boucher G, Lees CW, Franke A, D'Amato M, Taylor KD et al. Meta-analysis identifies 29 additional ulcerative colitis risk loci, increasing the number of confirmed associations to 47. Nat Genet 2011;43:246-252.

31. Mells GF, Floyd JA, Morley KI, Cordell HJ, Franklin CS, Shin SY et al. Genome-wide association study identifies 12 new susceptibility loci for primary biliary cirrhosis. Nat Genet 2011;43:329-332.

32. Shamim Z, Ryder LP, Heilmann C, Madsen H, Lauersen H, Andersen PK et al. Genetic polymorphisms in the genes encoding human interleukin-7 receptor-alpha: prognostic significance in allogeneic stem cell transplantation. Bone Marrow Transplant 2006;37:485-491.

33. Giliani S, Bonfim C, de Saint Basile G, Lanzi G, Brousse N, Koliski $A$ et al. Omenn syndrome in an infant with IL7RA gene mutation. J Pediatr 2006;148:272-274.

34. Shamim Z, Müller K, Svejgaard A, Poulsen LK, Bodtger $U$, Ryder LP. Association between genetic polymorphisms in the human interleukin-7 receptor alpha-chain and inhalation allergy. Int J Immunogenet 2007;34:149-151.

35. McKay FC, Swain LI, Schibeci SD, Rubio JP, Kilpatrick TJ, Heard RN et al. Haplotypes of the interleukin 7 receptor alpha gene are correlated with altered expression in whole blood cells in multiple sclerosis. Genes Immun 2008;9:1-6.

36. Monti P, Brigatti C, Krasmann M, Ziegler AG, Bonifacio E. Concentration and activity of the soluble form of the interleukin-7 receptor $\alpha$ in type 1 diabetes identifies an interplay between hyperglycemia and immune function. Diabetes 2013;62:2500-2508.

37. Kreft $K L$, Verbraak $E$, Wierenga-Wolf $A F$, van Meurs $M$, Oostra BA, Laman JD et al. Decreased systemic IL-7 and soluble IL-7Ra in multiple sclerosis patients. Genes Immun 2012;13:587-592.

Acceptance for editing: 2016-06-10 Acceptance for publication: 2016-06-23

Correspondence address: Paweł P. Jagodzinski Department of Biochemistry and Molecular Biology Poznan University of Medical Sciences 6 Święcickiego Street, 60-781 Poznań, Poland fax: +48618546510 email: pjagodzi@am.poznan.pl 